\title{
Prophylaxis against tetanus: An investigation into efficiency of a method
}

\author{
M. LAURENCE, L. B. HOLT, C. E. GRAHAM, AND G. L. W. BONNEY \\ From the Casualty Department, St. Mary's Hospital, \\ and the Wright-Fleming Institute of Microbiology, London
}

SYNOPSIS A study has been made by clinical methods and by bio-assay of the effectiveness of a régime for prophylaxis against tetanus. The two principal objects of the method were to ensure that active immunization was offered to all patients who had received antitoxin and to measure the effect of the combined administration of toxoid and antitoxin.

Because of a high incidence of failure to re-attend, $63.9 \%$ of patients requiring protection against tetanus would never have begun a course of active immunity unless toxoid had been given at the first attendance. The administration of antitoxin at the same time as the toxoid is given does not interfere with the latter's ability to provoke an immune response. A second injection of fluid toxoid produced a satisfactory immune response in $80.6 \%$ of subjects whose first dose had been given simultaneously with antitoxin.

\section{METHOD OF PROPHYLAXIS}

We assumed that protection was necessary in all patients in whom the skin surface was breached, unless they were wounded under conditions approaching those of surgical cleanliness.

All patients were classed according to their status of immunity and of sensitivity (Table I), and a procedure for prophylaxis was assigned to each of these classes (Table II). No further antitoxin was given to any patient who in response to a test dose developed any general reaction such as headache, malaise, nausea, tachycardia, flush, or pallor. Eleven reactions considered severe were observed. Of these, five took the form of immediate reactions to the first test dose and all of these had been classed in group A. The other six were generalized skin reactions with pyrexia commencing between six and 14

\section{TABLE I}

CLASSIFICATION OF PATIENTS ACCORDING TO IMMUNITY AND SENSITIVITY

\section{Group Numbers Immunity}

\begin{tabular}{|c|c|c|c|}
\hline $\mathbf{A}$ & 835 & $\begin{array}{l}\text { No previous active or } \\
\text { passive immunization }\end{array}$ & $\begin{array}{l}\text { No history of } \\
\text { sensitivity }\end{array}$ \\
\hline $\mathbf{B}$ & 151 & $\begin{array}{l}\text { Previous injection of } \\
\text { antitoxin (not within or } \\
\text { two weeks) }\end{array}$ & $\begin{array}{l}\text { History of sensitivity } \\
\text { (asthma, eczema, food } \\
\text { rashes, etc.) }\end{array}$ \\
\hline $\mathbf{C}$ & 366 & $\begin{array}{l}\text { Evidence of previous } \\
\text { active immunization }\end{array}$ & Not relevant \\
\hline $\mathbf{D}$ & NIL & $\begin{array}{l}\text { Antitoxin given within } \\
\text { the past two weeks }\end{array}$ & Not relevant \\
\hline Total & 1,352 & & \\
\hline
\end{tabular}

Received for publication 25 May 1964.

\section{TABLE II}

METHOD OF ACTIVE AND PASSIVE IMMUNIZATION ACCORDING TO STATUS OF IMMUNITY AND SENSITIVITY

\begin{tabular}{|c|c|c|c|c|c|}
\hline \multirow[t]{2}{*}{ Group } & \multicolumn{2}{|l|}{ Antitoxin } & \multicolumn{3}{|c|}{ Toxoid } \\
\hline & Test Doses & Full Doses & $\begin{array}{l}\text { First } \\
\text { Visit }\end{array}$ & $\begin{array}{l}A t \\
6 w k .\end{array}$ & $\begin{array}{l}\text { At } \\
6 \text { mth. }\end{array}$ \\
\hline $\begin{array}{l}\mathbf{A} \\
\mathbf{B}\end{array}$ & $\begin{array}{l}150 \text { units } \\
\text { (1) } 15 \text { units }\end{array}$ & 1,500 units & $5 \mathrm{Lf}$ & $5 \mathrm{Lf}$ & $5 \mathrm{Lf}$ \\
\hline & (2) 150 units & 1,500 units & $5 \mathrm{Lf}$ & $5 L f$ & $5 L f$ \\
\hline $\begin{array}{l}\text { C } \\
\text { D }\end{array}$ & - & 二 & $5 \mathrm{Lf}$ & $\overline{51 f}$ & $\overline{5 I f}$ \\
\hline
\end{tabular}

days after the injection. None was fatal and none was so severe as to require emergency administration of adrenalin or steroids. Local reactions, which occurred in about $30 \%$ of patients, were ignored. The antitoxin used was Wellcome enzyme-refined globulin. The toxoid was Wright-Fleming purified formal toxoid (dose 5Lf). There were no reactions to the toxoid.

All patients were given cards giving full explanations and instructions regarding future attendances.

\section{MATERIAL}

In the five months January to May 1960, 1,352 of the patients who attended the Casualty Department were judged to need prophylaxis against tetanus. Nine hundred and sixty-four ( $71 \%$ ) of these were male. Their ages were between 11 months and 86 years: two-thirds were between 10 and 40 years. Eight hundred and thirtyfive $(63.2 \%)$ were placed in group $A, 151(9.7 \%)$ were placed in group B, and $366(27.1 \%)$ were placed in group C. None qualified for group $D$. 
Thus, 986 patients (those in groups $\mathrm{A}$ and $\mathrm{B}$ ) were advised to attend for further injections after six weeks and again after six months. Six hundred and twenty-nine $(63.9 \%)$ did not return for the second injection and only $114(11 \cdot 6 \%)$ returned for the full course of injections.

\section{METHOD OF MEASURING IMMUNITY}

METHOD OF SAMPLING We classed all patients according to the number of injections that they had received: group I, initial dose of antitoxin with toxoid; group II, one injection of antitoxin with toxoid and one subsequent dose of toxiod; group III, one injection of antitoxin with toxoid and two subsequent doses of toxoid (Table III). We took too a control group of 21 adult volunteers who were given a single injection of fluid toxoid and who had had no previous prophylaxis of any sort against tetanus, and another control group of adults who had never had any tetanus prophylactic injections at all.

Patients were randomly selected from each group for estimation of their serum levels of antitoxin. The serum of all the volunteers was similarly examined.

MATERIAL One hundred and twenty-three specimens of serum were examined. Thirty-five patients had attended for the full course of three injections, 31 had attended

\section{TABLE III}

CLASSIFICATION OF PATIENTS ACCORDING TO NUMBER OF INJECTIONS RECEIVED AND DISTRIBUTION IN THE THREE GROUPS AND RESULTS

\begin{tabular}{|c|c|c|c|c|}
\hline Group & Injections & $\begin{array}{l}\text { No. of } \\
\text { Patients }\end{array}$ & $\begin{array}{l}\text { Percentage } \\
\text { Acquiring } \\
\text { Antitoxin Level } \\
\text { of } 0.01 \mathrm{u} . / \mathrm{ml} \text {. } \\
\text { or Greater }\end{array}$ & $\begin{array}{l}\text { No. Acquiring } \\
\text { Antitoxin Level } \\
\text { of } 0.01 \mathrm{u} . / \mathrm{ml} \text {. } \\
\text { or Greater } \\
\text { (estimated) }\end{array}$ \\
\hline I & $\begin{array}{l}1 \times 5 \text { Lf toxoid } \\
\text { with antitoxin }\end{array}$ & 629 & $20 \cdot 7$ & 126 \\
\hline II & $\begin{array}{l}2 \times 5 \mathrm{Lf} \text { toxoid } \\
\text { Antitoxin with the } \\
\text { first }\end{array}$ & 243 & $80 \cdot 6$ & 195 \\
\hline \multirow[t]{2}{*}{ III } & $\begin{array}{l}3 \times 5 \text { Lf toxoid } \\
\text { Antitoxin with the } \\
\text { first }\end{array}$ & 114 & 100 & 114 \\
\hline & Totals & 986 & & 435 \\
\hline
\end{tabular}

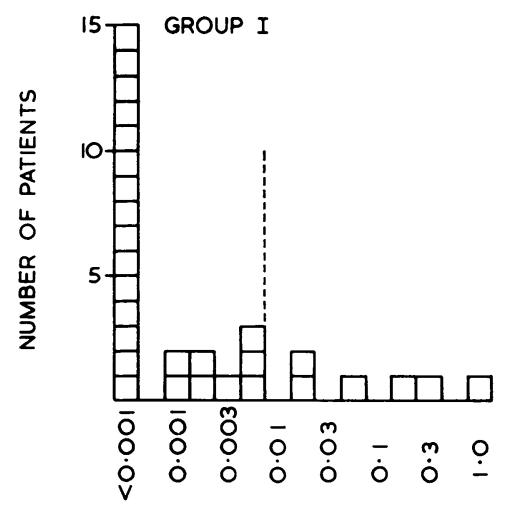

FIG. 2 twice, and 29 had had only the initial injections of antitoxin and toxoid. In addition, there were 28 contro? subjects; 21 of these had had one injection of toxoid and seven had had no injection at all.

In the control groups the serum titrations were made? six months after injection. In the patients the periods of time between the last injection and titration of the serun $\overline{\bar{c}}$ were as follows: group I, between three and 12 months $\mathbb{\Phi}$ average six months; group II, between five and 2 ? months, average 15 months; group III, between 13 ands 21 months, average 18 months.

METHOD OF ESTIMATION OF ANTIBODY LEVEL Antitoxirw titres were assayed on 15-20 g. mice using $\frac{L+}{2,000}$ dose o matured tetanus toxin, always controlled against M.R.C $\vec{\infty}$ standard antitoxin.

RESULTS

CLINICAL RESULTS There were no cases of tetanus among the patients attending the Casualty Depart? ment during the period of study.

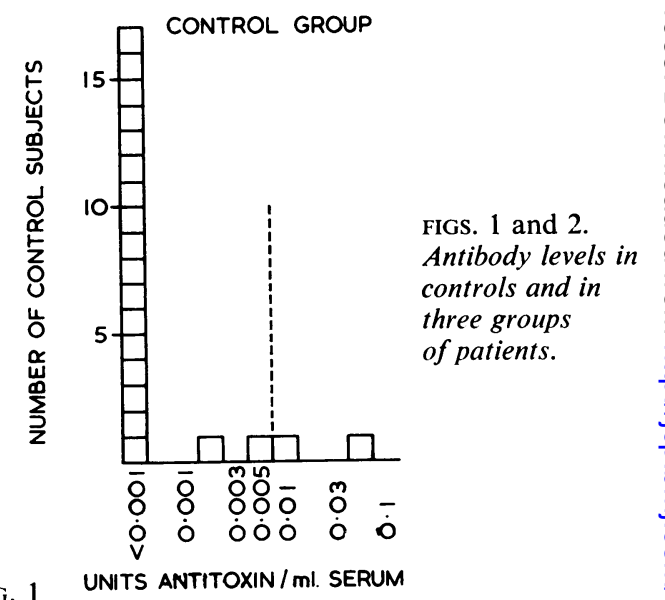

FIG. 1
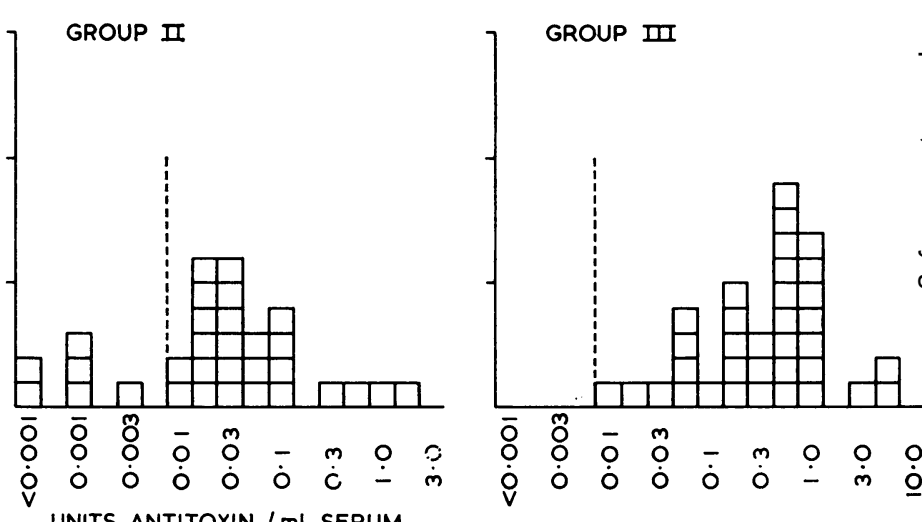

UNITS ANTITOXIN / mI. SERUM 
ANTIBODY LEVELS There were striking differences in the antibody levels obtained in the three clinical groups and in the control groups (Figs. 1 and 2). The median serum titres were as follows:

Control group (one injection) $\ldots<0.001 \mathrm{u} . / \mathrm{ml}$.
Group I $\ldots \ldots \ldots \ldots \ldots \ldots \ldots \ldots \ldots<0.001 \mathrm{u} . / \mathrm{ml}$.
Group II $\ldots \ldots \ldots \ldots \ldots \ldots \ldots \ldots \ldots .0 .03 \mathrm{u} . / \mathrm{ml}$.
Group III $\ldots \ldots \ldots \ldots \ldots \ldots \ldots \ldots .3-1 \cdot 0 \mathrm{u} . / \mathrm{ml}$.

In the base line control group, who had had no injections at all, there was no detectable level in any subject.

\section{DISCUSSION}

The basis of the work on active immunization was laid by Glenny and Südmersen (1921), who showed the value of a circulating actively produced antibody, and of the change occurring after active stimulation of the antitoxin-producing cells. This potential immunity expresses itself in the rapid and violent production of antitoxin when the sensitized organism is again exposed to the same antigen.

It was the view of the workers advising against the simultaneous administration of toxoid and antitoxin that the former would be completely neutralized by the much greater dose of antitoxin with consequent loss of antigenicity. However, the evidence for this neutralization is based on observations of antibody levels made 14 days after the injection, when, in theory, the peak titre should be reached (Barr and Sachs, 1955). Regamey, Simon, and Wantz (1955) have shown that there is only a small difference between the serum titres obtained by giving toxoid at the same time as antitoxin and those obtained when an interval of one month separates the injections. Miller, Ryan, and Beard (1949) failed to detect any significant difference in final titres when the toxoid and antitoxin were given simultaneously but into different limbs. Many others have advocated simultaneous injection of toxoid and antitoxin (Gold and Bachers, 1943; Eckmann and Bisaz, 1956; Fisher, 1956; Eckmann, 1958; Hubner, 1958; and Klingenberg and Maresch, 1958). Greenberg and Fleming (1950, 1951), investigating the neutralizing effect of antitoxin in active immunization against diphtheria, found that the excess antitoxin merely delayed the maximum development of actively produced antitoxin. The same results were reported by Tasman and Huygen (1962) with tetanus antitoxin and toxoid absorbed on to aluminium phosphate. They found that the response four weeks after injection was much better when the toxoid was given one month after the antitoxin. After seven months, however, the levels were the same whether the toxoid had been given at the same time as the antitoxin or an interval had separated the two injections.

Accepting the level of $0.01 \mathrm{u} . / \mathrm{ml}$. as adequate (Scheibel, 1955; Tasman and Huygen, 1962; Bergey, Brown, and Etris, 1939), we find that all patients in our group III obtained levels of more than this; $80 \%$ of those in group II obtained levels of over $0.01 \mathrm{u} . / \mathrm{ml}$. as did $20 \%$ of those in group I. Only $10 \%$ of those who received a single injection of toxoid without antitoxin developed an adequate level of circulating antibody.

Our results thus support the view that toxoid given at the same time as antitoxin can give a satisfactory initiating response. Eighty per cent of patients attending twice only acquired a satisfactory level of immunity. The responses in those who had a single injection of toxoid at the same time as an injection of antitoxin were certainly not inferior to those who had had a single injection of toxoid only. It seems reasonable to suppose that the nature of the interaction between these antagonistic proteins does not cause destruction of the toxoid, but that as the antitoxin is itself destroyed the toxoid is released from bondage and induces the immunity response over a longer period of time.

If we relate the figures for levels of immunity with those of re-attendance it seems likely that immunity was conferred on 435 patients (Table III), that is, $44.1 \%$ of all patients who had never received active immunization. Had the start of active immunization been delayed until the second visit, only about 163 patients (or $16 \%$ ) would have achieved immunity.

We have accepted that a single dose of toxoid, while unlikely to give a satisfactory level of immunity, would probably produce conditions in which a second dose would initiate an adequate secondary response. Thus we have classed in group $\mathrm{C}$ all who have had a single dose of toxoid as well as those who have had two doses. The degree of the immune response may be proportional to the interval between injections (Marvell and Parish, 1940; Bigler and Werner, 1941). Holt (1950) first described this as a tertiary response, but Barr and Llewellyn-Jones (1951) have shown that this particularly well maintained response is characteristic of that obtained when there is a long interval between injections. In our group II (Fig. 2) there were four patients who had their second injections of toxoid after a delay of five months or more. Their response to the second dose of toxoid was on the average high $(1 \cdot 5,0 \cdot 3,0 \cdot 1$, and $0.001 \mathrm{u} . / \mathrm{ml}$. after delays of $20,38,40$, and 22 weeks respectively).

We wish to acknowledge the invaluable work done by Sister D. Hopkin, S.R.N., her nurses and clerks, and the 
medical students in the Casualty Department of St. Mary's Hospital; also Miss Pamela Moritz, M.Sc., for her assistance with titrations, and Miss Joan Peek for the secretarial work entailed in this study.

\section{REFERENCES}

Barr, M., and Llewellyn-Jones, M. (1951). Brit. J. exp. Path., 32, 231. and Sachs, A. (1955). Army Path. Advis. Comm. Report on the Investigation into the Prevention of Tetanus in the British Army, London.

Bergey, D. H., Brown, C. P., and Etris, S. (1939). Amer. J. publ. Hlth, 29, 334.

Bigler, J. A., and Werner, M. (1941). J. Amer. med. Ass., 116, 2355.

Eckmann, L. (1958). Prakt. Arzt. (Wien), 12, 101.

-, and Bisaz, E. (1956). Schweiz. med. Wschr., 86, 641.
Fisher, J. (1956). Langenbecks Arch. klin. Chir., 284, 749.

Glenny, A. T., and Südmersen, H. J. (1921). J. Hyg. (Lond.), 20, 176으

Gold, H., and Bachers, H. (1943). J. Immunol., 47, 335.

Greenberg, L., and Fleming, D. S. (1950). J. Pediat., 36, 143.

- (1951). Ibid., 39, 672.

Holt, L. B. (1950). Developments in Diptheria. Prophylaxis. Heine-O mann, London.

Hubner, A. (1958). Dtsch. med. Wschr., 83, 555.

Klingenberg, H. G., and Maresch, W. (1958). Wien. klin. Wschr., 70, 606.

Marvell, D. M., and Parish, H. J. (1940). Brit. med. J., 2, 891.

Miller, J. J. Jr., Ryan, M. L., and Beard, R. R. (1949). Pediatrics, 3, 64.

Regamey, R. H., Simon, K., and Wantz, M. (1955). Schweiz. Z. allg? Path., 18, 1157.

Scheibel, I. (1955). Bull. Wld Hlth Org., 13, 381.

Tasman, A., and Huygen, F. J. A. (1962). Ibid, 26, 397. 